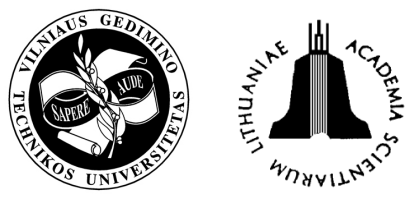

\title{
COMPARISON OF HIGH-SPEED TRANSPORTATION SYSTEMS IN SPECIAL CONSIDERATION OF INVESTMENT COSTS
}

\author{
Rainer Schach ${ }^{1}$, René Naumann ${ }^{2}$ \\ Technische Universität Dresden, Institute of Construction Management, D-01062 Dresden, Germany \\ E-mails: ${ }^{1}$ rainer.schach@tu-dresden.de; ${ }^{2}$ rnj@rcs.urz.tu-dresden.de
}

Received 27 July 2006; accepted 2 May 2007

\begin{abstract}
In this paper a substantial comparison of different high-speed transportation systems and an approach to stochastic cost estimations are provided. Starting from the developments in Europe, the high-speed traffic technical characteristics of high-speed railways and Maglev systems are compared. But for a comprehensive comparison more criterions must be included and led to a wider consideration and the development of a multi-criteria comparison of high-speed transportation systems. In the second part a stochastic approach to cost estimations of infrastructure projects is encouraged. Its advantages in comparison with the traditional proceeding are presented and exemplify the practical implementation.
\end{abstract}

Keywords: high-speed transportation; multi-criteria analysis; cost estimations; stochastic approach.

\section{Importance of high-speed transportation systems for Europe}

Mobility and infrastructure are essential preconditions for the growing together of Europe and the development of its regions like Schach, Jehle and Naumann [1] mention. Mobility is a primary need for the society. Grandjot [2] notices that it guarantees a high degree of freedom and quality of life for the citizens in their work and leisure time. Industry and trade rely on intensive goods traffic. A well constructed infrastructure is an important location factor in the regional and global sense. The development of the society, the economic growth of the national economies and the mobility of individuals and goods are not possible without an equivalent volume of traffic. For effective handling of traffic flow, it is necessary to establish integrated and sustainable traffic systems. So the promotion of the railway systems is a manifested aim of the European Union in order to relocate road and air traffic to rail and to reduce environmental stresses. But this relocating makes only sense, if the economic benefit is generated.

High-speed transportation systems are an important contribution to handle traffic volumes. Innovative systems, like the German Magnetically Levitated System Transrapid, and high-speed railways, like the German InterCityExpress (ICE) or the French Train à Grand Vitesse (TGV), offer high potentials. The European transport policy supports the development and implementation of high-speed railway transportation in particular through the Trans-European Transport Networks (TEN-T). Their development and implementation requires the interconnection and interoperability of national networks as well as the access to them. To achieve these objectives the European Community has established guidelines covering the objectives, priorities, the definition of projects of common interest and the main themes of the envisaged measures. The enlargement of the European Union led to rethinking the TEN-T and developing the Pan-European Corridors and Areas (see Fig 1). The Pan-European Corridors include ten road and rail corridors between West, Central and East Europe. About 20000 kilometres line sections of high-speed railway shall connect the important economic areas in Europe.

The enlargement of the European Union with ten new Member States offers the chance of sustainable increasing the economic power. For this purpose, the existing economic core area called the 'Blue Banana' is to be supported by a second economic core area, the "New Banana" (see Fig 2).

The development of economic core areas is influenced by the following aspects:

- the demographic development of the population with an increasing part of elderly people;

- the socio-economic development in conjunction with an increase of motorisation, disproportionate consumer spending of private budgets and increase of national/regional added value; 


\begin{tabular}{|c|l|}
\hline Corridor & \multicolumn{1}{|c|}{ Stations } \\
\hline I & $\begin{array}{l}\text { Helsinki - Tallinn - Riga - Kaunas and Klaipèda - Warsaw and Gdańsk } \\
\text { Branch A (Via/Rail Hanseatica) - Riga to Kaliningrad to Gdańsk } \\
\text { via Baltica (E 67) - Helsinki to Warsaw }\end{array}$ \\
\hline II & Berlin - Poznan - Warsaw - Brest - Minsk - Smolensk - Moscow - Nizhny Novgorod \\
\hline III & Brussels - Aachen - Köln - Dresden - Wrocław - Katowice - Kraków - L'viv - Kyiv \\
\hline IV & $\begin{array}{l}\text { Dresden/Nuremberg - Prague - Vienna - Bratislava - Györ - Budapest - Arad - Constanța / Craiova - Sofia - } \\
\text { Thessaloniki / Plovdiv - Istanbul }\end{array}$ \\
\hline V & $\begin{array}{l}\text { Venice - Trieste/Koper - Ljubljana - Maribor - Budapest - Uzhhorod - L'viv - Kyiv } \\
\text { Branch A - Bratislava - Žilina - Kǒ̌ice - Uzhhorod } \\
\text { Branch B - Rijeka - Zagreb - Budapest } \\
\text { Branch C - Ploče - Sarajevo - Osijek - Budapest }\end{array}$ \\
\hline VI & Gdańsk - Katowice - Žilina, with a western branch Katowice - Brno \\
\hline VII & The Danube River - Northwest-Southeast \\
\hline VIII & Durrës - Tirana - Skopje - Bitola - Sofia - Dimitrovgrad - Burgas - Varna \\
\hline IX & $\begin{array}{l}\text { Helsinki - Vyborg - St. Petersburg - Pskov - Moscow - Kaliningrad - Kyiv - Ljubashevka/Rozdilna (Ukraine) - } \\
\text { Chisinau - Bucharest - Dimitrovgrad - Alexandroupolis. A branch runs from Ljubashevka/Rozdilna to Odessa } \\
\text { Branch A - Helsinki to St. Petersburg to Moscow } \\
\text { Branch B - Kaliningrad to Kyiv } \\
\text { Branch C - Kaliningrad to Vilnius to Minsk }\end{array}$ \\
\hline X & $\begin{array}{l}\text { Salzburg - Ljubljana - Zagreb - Beograd - Niš - Skopje - Veles - Thessaloniki } \\
\text { Branch A: Graz - Maribor - Zagreb } \\
\text { Branch B: Budapest - Novi Sad - Beograd } \\
\text { Branch C: Niš - Sofia - Dimitrovgrad - Istanbul via Corridor IV } \\
\text { Branch D: Veles - Prilep - Bitola - Florina - Igoumenitsa }\end{array}$ \\
\hline
\end{tabular}

Fig 1. Pan-European corridors and areas

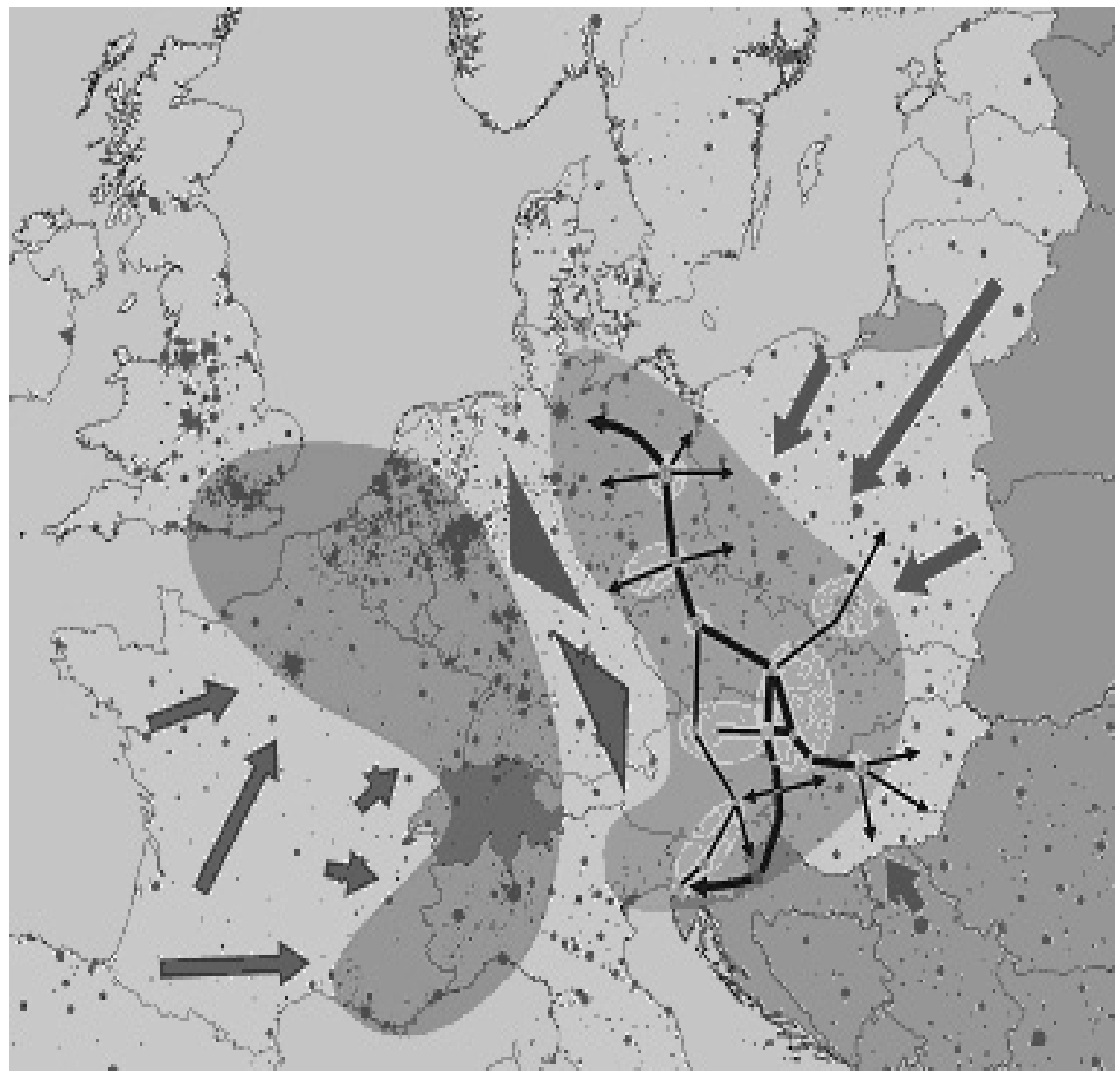

Fig 2. Development of a second economic core area in Central-East-Europe (source IPE GmbH, Wien) 
- the high economic growth of the new Member States;

- the progressive globalisation;

- the rapid technological development.

It may be expected, that these developments will lead to a considerable increase of road and goods traffic, a capacity overload of the European road traffic network, e. g. in East-west-direction, and an increase of stresses for people and environment. The transport policy must be faced up to this challenge and take appropriate measures in time. A major vision is the development and implementation of the Trans-European Transport Network (TEN-T) for railways, which might be able to relocate certain parts of road and air traffic to more ecological railway systems and to enhance the growth of the European congested urban areas and the coalescence of the European Economic Area.

These developments are in the focus of the European research project "Sustrain Implement Corridor - SIC!" (www.sustrain.net). One important part is the module high-speed transportation. In this module a high-speed transportation line between Berlin - Dresden - Prague Brno - Vienna - Bratislava - Budapest in the PanEuropean Corridor IV is analysed. The principal is the Saxony Ministry of the Interior (SMI). The agents are the Austrian IPE "Integrierte Planung und Entwicklung regionaler Transport- und Versorgungssysteme GmbH' Wien", the "Institut für Bahntechnik" (Institute of Railway Technology), branch office Dresden, and the "Kompetenzzentrum für Hochleistungsbahnen und Magnetbahnsysteme" (Center of Excellence for High Performance Railways and Maglev Systems) at the "Technische Universität Dresden" (www.hochleistungsbahnen.tu-dresden.de).

A high-speed railway or Maglev system has to fulfil the major elements of the transport policy and should be able to close the gap between road, air and railway transportation. The major aims for the implementation of high-speed railway systems are the increase of speed in the transportation corridors, flexibility, networking and the environmental compatibility. These aims result in a series of requirements:

- $\quad$ high speed;

- high railway frequency;

- high safety and reliability;

- high flexibility;

- high ride comfort;

- low costs;

- low stresses (noise, pollution, vibrancies);

- low energy consumption.

Schach, Jehle and Naumann [1] notice that the highspeed railway systems comply with most of these demands. But in comparison with the Maglev system Transrapid it appears that the Transrapid is superiorly.

Investments in the transportation infrastructure are long-term investments for the future. The provision of these investments on a certain high level has to stay essentially also in future in order to guarantee the efficiency of the transportation networks. Besides microeconomic and economic aspects, the environmental, competitive and industry political aspects are significant as well.

\section{High-speed railway and Maglev systems}

For high-speed transportation two different systems exist in parallel. These are in the first place the conventional high speed railways, like the German InterCityExpress (ICE) (see Fig 3 right), the Spanish AVE or the French Train à Grande Vitesse (TGV) and in the second place the German Magnetic Levitated System Transrapid (see Fig 3 left).

The following comparison of technical data between ICE and Transrapid is given. Selected technical parameters are shown in Table 1.

The travel speed of the high-speed railways depends strongly on the distance between the stations and mostly ranges between approx. $130 \mathrm{~km} / \mathrm{h}$ and $220 \mathrm{~km} / \mathrm{h}$. The Transrapid is achieving a travel speed of approx.

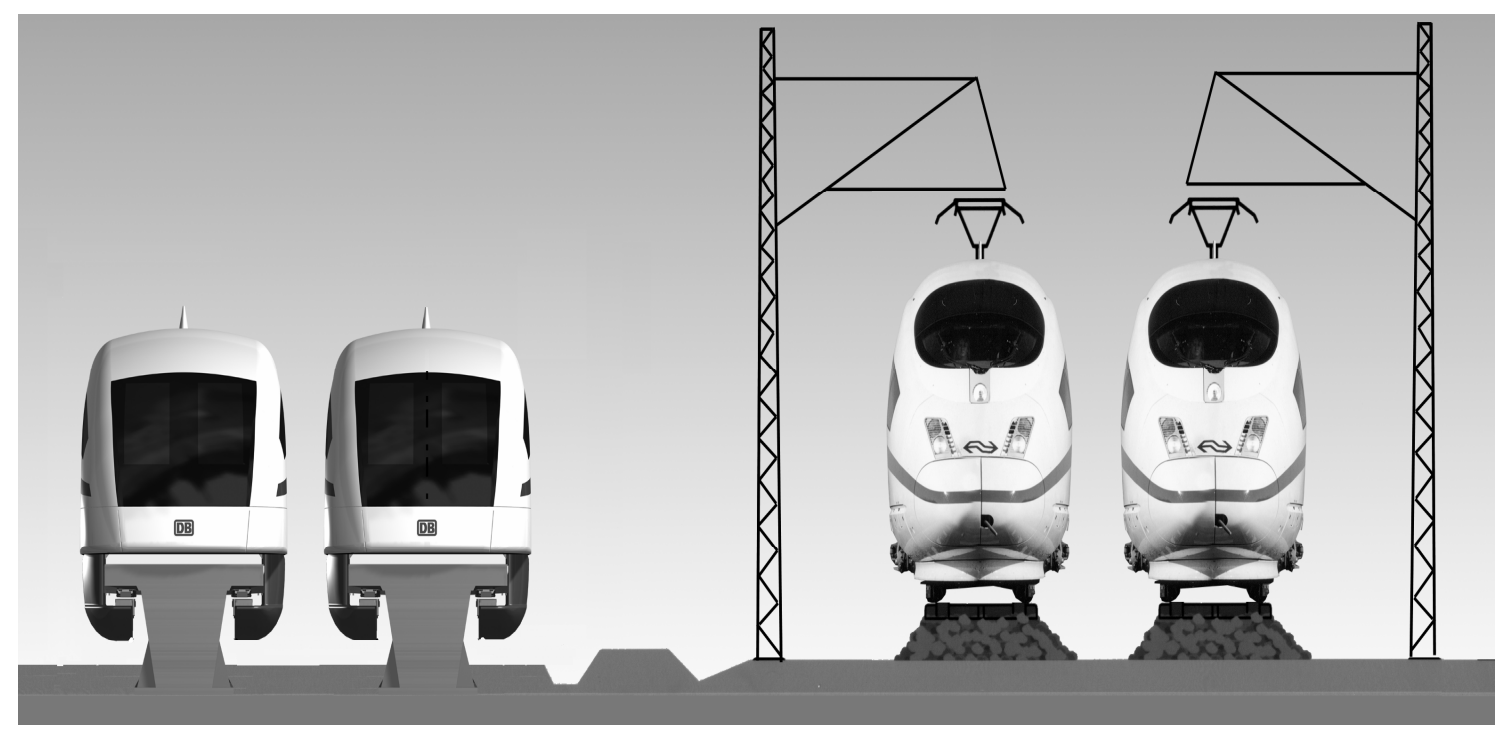

Fig 3. Transrapid and InterCityExpress (ICE) 
Table 1. Comparison between technical parameters of the ICE and the Transrapid

\begin{tabular}{|c|c|c|}
\hline Parameters & InterCityExpress (ICE) $3^{*}$ & Transrapid $^{* *}$ \\
\hline Active principle & $\begin{array}{l}\text { load transmission and guidance by wheel } \\
\text { and rail }\end{array}$ & $\begin{array}{l}\text { load transmission and guidance by elec- } \\
\text { tromechanical fields }\end{array}$ \\
\hline Wear & high & none \\
\hline Operational control & by train driver & without a leader \\
\hline Traffic safety & high & very high \\
\hline Operational maximum speed & until $300 \mathrm{~km} / \mathrm{h}$ & until $450 \mathrm{~km} / \mathrm{h}$ \\
\hline Sections per vehicle & 8 & 5 (from 2 to 10 possible) \\
\hline Seats (on average) & 415 & 438 \\
\hline Maximum engine performance & $8.000 \mathrm{kV}$ & approx. $25.000 \mathrm{~kW}$ \\
\hline Net weight vehicle & $409 \mathrm{t}$ & $247,3 \mathrm{t}$ \\
\hline Width & $2,95 \mathrm{~m}$ & $3,70 \mathrm{~m}$ \\
\hline Lenght (total) & $200 \mathrm{~m}$ & $128,3 \mathrm{~m}$ \\
\hline Load & axle load $16 \mathrm{t}$ & load per unit length $2,2 \mathrm{t} / \mathrm{m}$ \\
\hline \multicolumn{3}{|l|}{ Sound emissions } \\
\hline - at $200 \mathrm{~km} / \mathrm{h}$ & $85 \mathrm{~dB}$ & $73 \mathrm{~dB}$ \\
\hline - at $300 \mathrm{~km} / \mathrm{h}$ & $90 \mathrm{~dB}$ & $80 \mathrm{~dB}$ \\
\hline - at $400 \mathrm{~km} / \mathrm{h}$ & - & $91 \mathrm{~dB}$ \\
\hline \multicolumn{3}{|l|}{ Route planning } \\
\hline - Maximum longitudinal gradient & $3,5 \%$ & $10 \%$ \\
\hline - Maximum transverse gradient & $6,5 \%$ & $12 \%$ \\
\hline Acceleration & maximum $1,0 \mathrm{~m} / \mathrm{s}^{2}$ & constant $1,5 \mathrm{~m} / \mathrm{s}^{2}$ \\
\hline
\end{tabular}

$300 \mathrm{~km} / \mathrm{h}$. This represents approximately $67 \%$ of the operational maximum speed and is caused by better acceleration especially at high speeds. Therefore the Transrapid is the more attractive transportation system. On the one hand it is particularly suitable for premium peer-topeer-transportation-links with a high traffic volume like the planned Transrapid in Munich (Germany). On the other hand it is particularly suitable for long-distance transportation of passengers. The Transrapid is able to compete with air transportation at distances between 400 and 700 kilometres and against passenger cars at distances starting from 100 kilometres. In contrast to that, the high-speed railway systems are only conditionally able to compete with passenger cars at distances up to approx. 100 kilometres and beyond with air traffic.

\section{A multidimensional and multi-criteria comparison of high-speed railway and Maglev systems}

Before a high-speed railway or Maglev system can be erected, it has to prove its advantages towards possible versions. For this process, extensive and detailed studies and planning are carried out. The investment costs for the transportation infrastructure play a key role within this comparison. Because of their amounts, they have to be examined in an intense planning process with feasibility studies, economic estimations and arrangements for financing. Often this process takes many years and is a multi-level procedure.
The contributing factors for the realisation of a specific project are various criterions, which must be evaluated in a multi-criteria procedure. For traditional transportation systems like railway traffic, microeconomic and environmental aspects are standing in front. For new transportation systems like the Maglev system Transrapid the evaluation should be carried out more distinguishably and has to include economic and industry political aspects for the decision of realisation.

In Germany decisions for the realisation of traffic projects, e. g. track sections for high-speed railways, are made in the framework of the national general planning for the transportation routes. This multi-level process delivers a master plan for new construction, upgrading and maintenance of the transportation infrastructure. The master plan reflects the political aims e. g. the implementation of the Trans-European Transport Network. Prognoses are the basis for the planning of traffic volumes and financing provisions. Under these conditions, all projects are evaluated and prioritised in the planning process. The major criterions for decision making are:

- the cost-value ratio from the cost-benefit analysis;

- the results of an analysis to spatial effects;

- the results of an analysis to environmental risks;

- the results of an analysis to effects on flora, fauna and habitat. 
The cost-value ratio is based on a monetary dimension for the evaluation. The other criterions are qualitative and their effects are of non-monetary dimensions. Therefore Schach, Jehle and Naumann [1] transformed them into a monetary dimension in order to be integrated into the cost-value ratio and the decision making process. The ultimate decision, whether a traffic project will be realised or not, is not only based on the cost-value ratio. Rath [3] mentions, that the ultimate decision is affected by political influences and taken by the political decision maker.

The major element in the evaluation process for different traffic projects is the multi-level and standardised evaluation method. Its character is based on the cost-benefit-analysis. The aim is to determine a specific cost-value ratio of each project with the present value of the benefits as numerator and the present value of the investment costs in the denominator. For the determination, the components shown in Table 2 are economically evaluated and used for decision making.

Table 2. Components for evaluation in the cost-benefitanalysis in the German general transportation planning

\begin{tabular}{|c|l|}
\hline Abbreviation & \multicolumn{1}{|c|}{ Description } \\
\hline NB & Costs of transportation \\
\hline NW & Maintenance of traffic routes \\
\hline NS & Transportation safety \\
\hline NE & Availability \\
\hline NR & Spatial effects \\
\hline NU & Environmental effects \\
\hline NI & Induced traffic \\
\hline NH & $\begin{array}{l}\text { Transport connections of seaports and air- } \\
\text { ports }\end{array}$ \\
\hline K & Investment costs \\
\hline
\end{tabular}

For the comparison of project alternatives as highspeed railway or Maglev system, the method of the German general transportation planning is only partly suitable. It is concentrated on many criterions like traffic, microeconomic and environmental aspects. But economic and industry political aspects are neglected. Furthermore the method is based on a primary monetary evaluation dimension. This restriction is questionable for multiplecriteria analyses because of the problems if effects are transformed into a monetary dimension e. g. for traffic accidents, environmental consequences or time savings.

Schach, Jehle and Naumann [1] propose a multidimensional and multi-criteria comparison for highspeed railways and Maglev systems, which is based on the principle of the value benefit analysis. Their method is as well multi-dimensional because of four different simultaneously interested groups as well multicriteria because of technical, microeconomic and economic evaluation criterions and the involvement of effects for transportation and industry. For the evaluation process, they adapt the basic structure of the value benefit analysis, because of their evaluation dimension and their modifiability. But their approach is done without a weighting of the aim criterions and the aggregation of part benefits. This partial step is critical because of its subjectivity. The decision-makers have to consider several issues, such as cost, technology, sustainability and equity. These objectives are conflicting and, therefore, it is difficult to find an optimised solution like Pokharel and Chandrashekar [4] mention.

Also the formalisation and automation of the ultimate decision making through possible weightings and aggregations is not intended. It is left to the decisionmaker. Instead of that, the results of the four perspectives in the decision making process are maintained and the ultimate decision making is left to the observer.

The basis for the comparison of high-speed transportation systems is a hierarchical structured system of aim criterions (see Table 3 ). These aim criterions represent the different expectations of the four different interested groups - users, operating company, society and policy. These groups are partly interested in common aims but have got different and contrary expectations as well. For an evaluation, the focus must be aligned with the particular interested groups.

For the multi-level and multi-dimensional evaluation of the aim criterions, the proceeding of the value benefit analysis is adopted and a scaled dimension is used. For this dimension an evaluation to the following classes is taken:

++ completely fulfilled;

$+\quad$ aim criteria almost fulfilled;

$\pm \quad$ aim criteria partially fulfilled;

- $\quad$ aim criteria scarcely fulfilled;

- - aim criteria not fulfilled;

$\mathrm{p}$ fulfilment specific for a project.

Schach, Jehle and Naumann [1] in their comparison of the German high-speed railway ICE and the Maglev system Transrapid arrive at the conclusion, that the Transrapid outplays the ICE at many criterions and in some criterions even pronouncedly. Its technical preferences, its profitability and its environmental preferences make it to an exceptional transportation system.

\section{Cost estimations for transportation infrastructure projects}

The realisation, e.g. planning, construction, operation and deconstruction of transportation infrastructure is often entailed by high investment costs. The investment costs are target-orientated, long-term capital commitments for future incomes. Investments in infrastructure are characterised by long-term durations, because of the long-term physical and economical life, and by high investment costs, because of the project volumes. In addition the investments are determined by the fundamental uncertainty of the economic success and the profitability. They are leading to high risks for the investor. The profitability is the major criterion for its enforceability and its success. Profitability is the sustainable favourite ratio of the benefits concerning the degree of the fulfilment of the aim criterions and the costs of resources, victims and negative effects. 
Table 3. System of aim criterions for the multi-dimensional and multi-criteria comparison

\begin{tabular}{|c|c|}
\hline No & Interested group/Aim criteria \\
\hline 1 & Users \\
\hline 1.1 & Overall travel time (travel speed/travel time, stations, transportation rate) \\
\hline 1.2 & Costs (fare, additional costs) \\
\hline 1.3 & $\begin{array}{l}\text { Comfort (punctuality/availability, seats, entrance/egress, air conditioning, noise inside, baggage, passenger compartment, } \\
\text { attractiveness/image, safety sensation, classes of comfort, interior) }\end{array}$ \\
\hline 2 & Operating company \\
\hline 2.1 & Maximisation of the incomes (fare incomes, parking places, useful areas in stations) \\
\hline 2.2 & Minimisation of the investment costs (track system, vehicles, operational constructions, indirect costs, land acquisitions) \\
\hline 2.3 & Minimisation of the operational costs (track system, vehicles, staff, energy) \\
\hline 2.4 & $\begin{array}{l}\text { Maximisation of the safety (level of automation, braking, fire protection, evacuation, construction of the track system, } \\
\text { collision risk) }\end{array}$ \\
\hline 2.5 & Maximisation of the availability, the image and the reliability (failure risk, technical availability, attractiveness, image) \\
\hline 3 & Society \\
\hline 3.1 & $\begin{array}{l}\text { Reduction of negative environmental effects (pollution, noise emissions, vibrancies, land use, water supply, regional } \\
\text { scenery, townscape, division effects/separation) }\end{array}$ \\
\hline 3.2 & Increase of safety (reduction of deaths, seriously injured persons, slightly injured persons and material damages) \\
\hline 3.3 & $\begin{array}{l}\text { Improvement of the settlement and spatial structure (connections metropolis/ congested areas, coverage of rural areas, } \\
\text { networking national and European) }\end{array}$ \\
\hline 4 & Policy \\
\hline 4.1 & $\begin{array}{l}\text { Transport policy (mobility, business locations, volume of traffic, transportation safety, resources consumption, emissions, } \\
\text { European coalescence, transportation systems) }\end{array}$ \\
\hline 4.2 & $\begin{array}{l}\text { Economy (productiveness/division of labour, regional economic structure, settlement and spatial structure, economic cy- } \\
\text { cle/economic growth, external costs) }\end{array}$ \\
\hline 4.3 & Policy for the industry (job market/employment, innovations, export chances, development potential, structural change) \\
\hline
\end{tabular}

In profitability estimations of high-speed railway and Maglev systems, the following main criterions of different sections have to be included:

- economy (market potential, profit prognoses, etc.);

- development (research, development costs, etc.);

- technology (safety, ecology, capability, etc.);

- routing (line management, bridges, tunnels, noise protection, etc.);

- consumption of resources;

- investment costs.

For the comparison of the profitability of investments, standardised cost structures are used. Table 4 shows the cost structures which were developed for the cost estimations of high-speed railway ICE and Maglev system Transrapid in the research project "SIC! Modul HGV". At the core the cost structure is set up analogously and includes the main cost types: operation and control systems, vehicles, guideway, planning costs and operational costs. But the cost structures are different in some subcost types because of the different kinds of technology, especially the propulsion. For example, the subcost type R 1.1 for high-speed railway includes the costs for overhead contact lines and the subcost type M 1.1 includes the costs for the propulsion system. Additionally the Transrapid can be mounted either at-grade or elevated. The elevated guideway is advantageous in many ways, e. g. less crossover constructions or less cutting of landscape. These advantages appear in different subcost types.

\section{Deterministic approach to cost estimations}

Traditionally in cost estimations the expected investment costs for infrastructures are determined as the product of an expected quantity and a cost ratio:

$$
K_{\text {ges }}=\sum_{i=1}^{n}\left(m_{i} \cdot k_{i}\right) \text {, }
$$

where $i$ - cost type; $m_{i}$ - quantity for each cost type (e. g. $5.000 \mathrm{~m}^{3}$ ); $k_{i}$ - cost ratio (e. g. $22,00 / \mathrm{m}^{3}$ ).

The quantities for the cost estimations are usually determined in different profundities on the basis of the planning and the line routing. The cost ratios are deterministically calculated out of finished projects. Subjected to the planning level the quantities $m_{i}$ and the cost ratios $k_{i}$ are afflicted with uncertainties. On the one hand each project has got its own specific cost ratio, but on the other hand, the accuracy of these cost ratios are determined by the planning expenditure. Therefore the cost ratios $k_{i}$ vary for each project and are influenced by many factors, e. g. the building ground, the specific construction or the situation of the competition. Moreover, the cost ratios are only fixed in building contracts. Furthermore the quantities $m_{i}$ for estimating vary as well. And the ultimate quantities are in the first place fixed in the billing.

Especially in the planning stage the quantities and cost ratios are closely connected with a high degree of 
Table 4. Cost structures for the high-speed railway and the Maglev system Transrapid

\begin{tabular}{|c|c|c|c|}
\hline $\begin{array}{l}\text { Kosten- } \\
\text { gruppe }\end{array}$ & Bezeichnung & $\begin{array}{l}\text { Kosten- } \\
\text { gruppe }\end{array}$ & Bezeichnung \\
\hline R 1 & Betriebssystem & M1 & Betriebssystem \\
\hline R 1.1 & Oberleitung & M1.1 & MSB-Antrieb \\
\hline R 1.2 & Energieversorgung & M 1.2 & Energieversorgung \\
\hline R 1.3 & Leit- und Sicherungstechnik & M 1.3 & Betriebsleittechnik \\
\hline R 1.4 & Bauliche Anlagen; Betriebssystem & M 1.4 & MSB-Betriebsanlagen; MSB-Stationen \\
\hline $\mathbf{R} 2$ & Fahrzeuge & M 2 & Fahrzeuge \\
\hline R 2.1 & ICE-Züge & M 2.1 & MSB-Fahrzeuge \\
\hline R 2.2 & Instandhaltungsfahrzeug & M 2.2 & MSB-Betriebsfahrzeuge \\
\hline R 3 & Fahrweg & M 3 & Fahrweg \\
\hline R 3.1 & Grundstückskosten & M 3.1 & Grundstückskosten \\
\hline R 3.1.1 & Grunderwerb & M 3.1.1 & Grunderwerb \\
\hline R 3.1 .2 & Grundstücknebenskosten & M 3.1.2 & Grundstücksnebenkosten \\
\hline R 3.2 & Fahrwegoberbau und -unterbau & M 3.2 & Fahrwegüberbau und -unterbau \\
\hline R 3.2 .1 & Fahrwegoberbau & M 3.2.1 & Fahrwegüberbau \\
\hline R 3.2 .2 & Fahrwegunterbau & M 3.2.2 & Fahrwegunterbau \\
\hline R 3.3 & Spurwechseleinrichtungen/ Weichen & M 3.3 & Spurwechseleinrichtungen \\
\hline R 3.4 & Sonderbauwerke & M 3.4 & Sonderbauwerke \\
\hline R 3.4 .1 & Tunnel & M 3.4.1 & Tunnel \\
\hline R 3.4 .2 & Brücken & M 3.4.2 & Brücken \\
\hline R 3.4 .3 & Straßenüberführungen & M 3.4.3 & Straßenüberführungen \\
\hline R 3.5 & Bauliche Anlagen & M 3.5 & Bauliche Anlagen \\
\hline R 3.5 .1 & Stationen & M 3.5.1 & Stationen \\
\hline R 3.5 .2 & Schutzanlagen & M 3.5.2 & Schutzanlagen \\
\hline R 3.5 .3 & Sonstige Anlagen & M 3.5.3 & Sonstige Anlagen \\
\hline R 3.6 & Landschaftspflegerische Begleitmaßnahmen & M 3.6 & Landschaftspflegerische Begleitmaßnahmen \\
\hline R 3.7 & Mittelbare Kosten & M 3.7 & Mittelbare Kosten \\
\hline R4 & Planungskosten & M 4 & Planungskosten \\
\hline R 4.1 & Planungskosten & M 4.1 & Planungskosten \\
\hline R 4.2 & Projektmanagement & M 4.2 & Projektmanagement \\
\hline R 4.3 & Gebühren, Beiträge, Vorlaufkosten, etc. & M 4.3 & Gebühren, Beiträge, Vorlaufkosten, etc. \\
\hline R 5 & Betriebskosten & M 5 & Betriebskosten \\
\hline
\end{tabular}

uncertainty. Traditionally these uncertainties are paid little attention and the cost ratios are estimated deterministically (e. g. 5,- $/ \mathrm{m}^{2}$ ). A careful attention leads to the conclusion that these proceedings can not satisfy. Deterministic estimations are easy to use, because simple multiplications and additions lead to a definite result. So the investment costs for a specific line can be specified with e. g. 1,145,788588.32 . It is commonly known that the settled costs will vary. So accuracy that does not factually exist is pretended. Schach [5] emphasises that in traditional deterministic cost estimations, usually, risk analyses are carried out, but these results are not comparable to stochastic examinations.

\section{Stochastic approach to cost estimations}

In order to take the inevitable hidden uncertainties and risks into consideration, a stochastic proceeding for cost estimations seems advisable. The future uncertainties can be estimated e. g. by using multi-stage stochas- tic programming like Kanudia and Loulou [6] show. Moreover, Schach and Naumann [5] developed a stochastic approach with stochastic distributions for the cost ratios $k_{i}$. The risks become apparent and can be attended. The total costs with a large number of stochastic elements are estimated by Monte-Carlosimulation or Latin- Hypercube-simulation using special software, e.g. Palisade's @Risk (www.palisadeeurope.com). So the expenditure stays acceptable. The cost distributions can be deduced from finished projects or by expert knowledge. The software provides a multiplicity of different distributions which can be modified easily. Especially the triangle, uniform and pert distributions (see Fig 4) are appropriated for modelling cost functions.

The recommended approach to cost estimations is a method which is transcending traditional cost estimations. Risks can be involved individually for each cost ratio. So the investor is getting information about the 


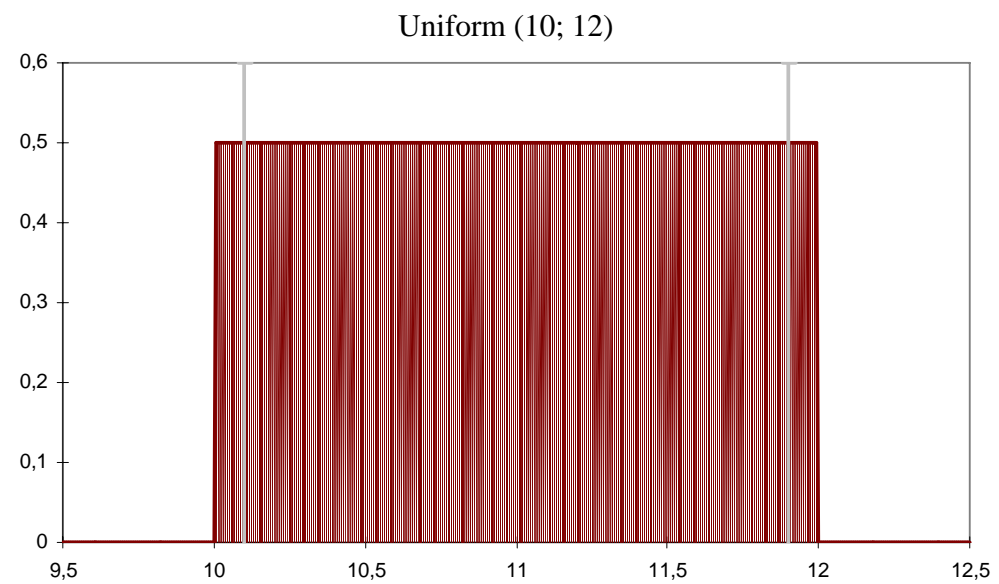

Triang $(3 ; 3,5 ; 5)$

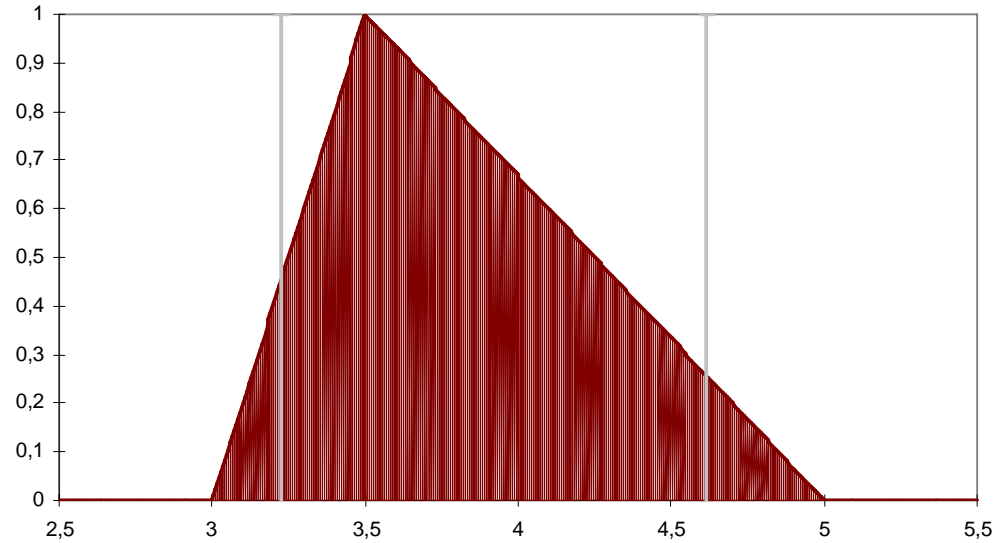

Pert $(1 ; 3,1 ; 11,4)$

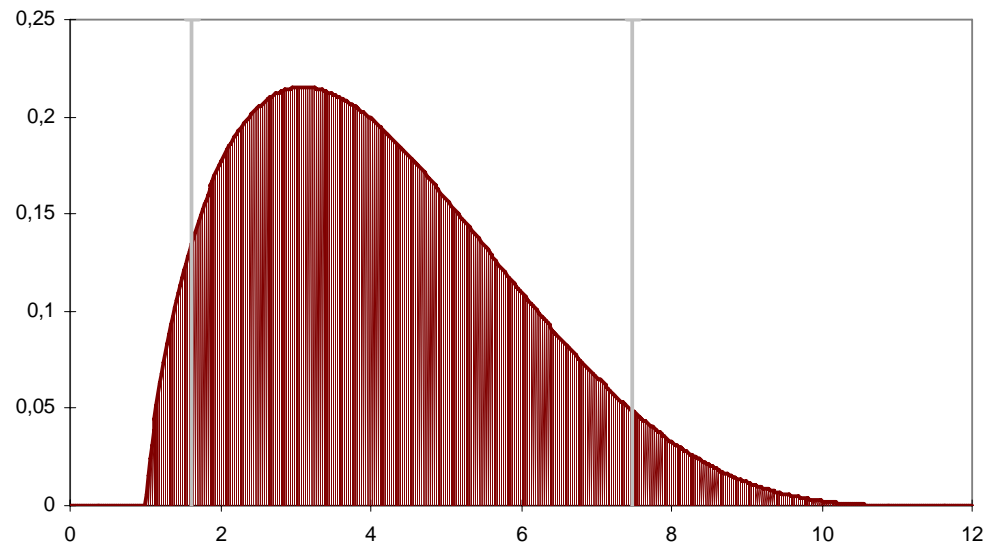

Fig 4. Selected distributions for cost ratios

scope of the expected costs for a definite probability, e. g. $90 \%$. Therefore a stochastic estimation can deliver the result for a specific line, e. g. an expectation value of $1,145,788,588.32$ and a scope of costs between $965,899,779.72$ and 1,372,654,728.23 for a probability of $90 \%$.

Schach et al. [1] carried out different cost estimations for a fictive line section of 100 kilometres of either high-speed railway ICE or Maglev system Transrapid. In
Fig 5 some results of simulations for the construction costs (without operation and control systems and vehicles) are shown as distributions of the cumulative frequency. The mean costs for the Transrapid amount to 21.53 million / double track $\mathrm{km}$ and for the highspeed railway to 17.69 million / double track $\mathrm{km}$. The $5 \%$-quantil is with $6.87 \%$ below the mean of the Transrapid (20.05 million / double track km divided by 21.53 million / double track $\mathrm{km}$ ) and for the high- 

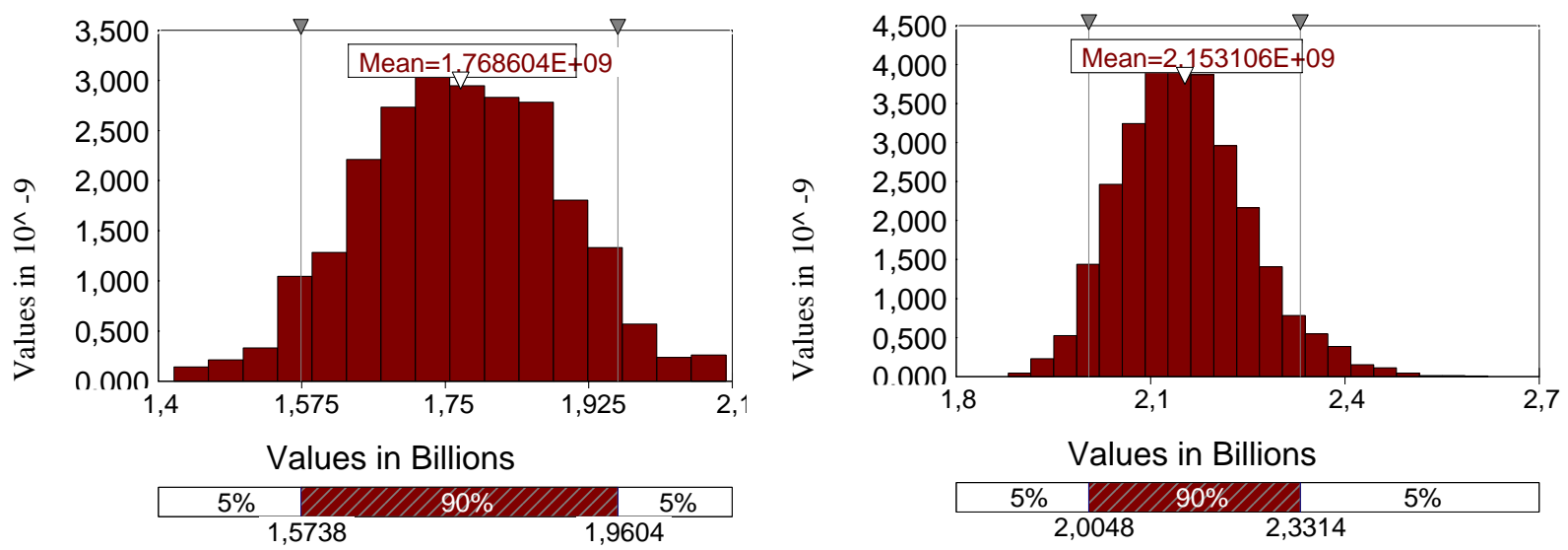

Fig 5. Comparison of estimated investment costs for the ICE (left graph) and the Transrapid (right graph)

speed railway with $11.08 \%$ below the mean (15.73 million / double track $\mathrm{km}$ divided by 17.69 million / double track $\mathrm{km}$ ). The upper Quantiles of the high-speed railway with $10.80 \%$ (19.60 million / double track $\mathrm{km}$ divided by 17.69 million / double track $\mathrm{km}$ ) are farther away from the mean than of the Transrapid with $8.27 \%$ (23.31 million / double track $\mathrm{km}$ divided by 21.53 million / double track $\mathrm{km}$ ). It is even clearer for the standard deviation. For the high-speed railway it amounts to 1.024 million / double track $\mathrm{km}$ and for the Transrapid only to 0.456 million / double track $\mathrm{km}$. That shows the smaller risk of cost overrun for the Transrapid. Schach [5] sees the main reason in the higher ratio of tunnels for the high-speed railway. They are necessary, especially because of the lower gradeability of railways ( $3.5 \%$ to $10 \%$ for the Transrapid).

\section{Conclusion and future work}

The recommended approach and the carried out cost estimations show that stochastic cost estimations provide some advantages concerning the involvement and the representation of different risks.

So far the carried out cost estimations were only taken by stochastic cost ratios.

Further researches are necessary to analyse the effects of stochastic quantities.

\section{References}

1. SCHACH, R.; JEHLE, P.; NAUMANN, R. Transrapid und Rad-Schiene-Hochgeschwindigkeitsbahn - Ein gesamtheitlicher Systemvergleich. Berlin Heidelberg: Springer-Verlag, 2006.

2. GRANDJOT, H.-H. Verkehrspolitik - Grundlagen, Funktionen und Perspektiven für Wissenschaft und Praxis. Hamburg: Deutscher Verkehrs-Verlag, 2002.

3. RATH, A. Möglichkeiten und Grenzen der Durchsetzung neuer Verkehrstechnologien dargestellt am Beispiel des Magnetbahnsystems Transrapid. Berlin: Duncker \& Humblot, 1993.

4. POKHAREL, S.; CHANDRASHEKAR, M. Revisiting rural energy analysis. International Journal of Environment and Pollution, 1999, Vol 12, No 2/3, p. 179-190.
5. SCHACH, R.; NAUMANN, R. Stochastische Investitionskostenberechnung für Verkehrsinfrastrukturprojekte. In Proceedings of 5th Dresdner Fachtagung Transrapid, Dresden, Germany, September, 2005, p. 109.

6. KANUDIA, A.; LOULOU, R. Advanced bottom-up modelling for national and regional energy planning in response to climate. International Journal of Environment and Pollution, 1999, Vol 12, No 2/3, p. 191-216. 